\title{
Diesel-Like Biofuels Production Using Fatty Waste
}

\author{
Lyvia N. B. Menezes, ${ }^{\oplus a}$ Paulo A. Z. Suarez ${ }^{\circledR * a}$ and Grace F. Ghesti ${ }^{\odot *, b}$ \\ ${ }^{a}$ Laboratório de Materiais e Combustíveis (LMC), Instituto de Química, \\ Universidade de Brasília, 70910-900 Brasília-DF, Brazil \\ ${ }^{b}$ Laboratório de Bioprocessos Cervejeiros e Catálise Aplicada a Energias Renováveis (LaBCCERVA), \\ Instituto de Química, Universidade de Brasília, 70910-900 Brasília-DF, Brazil
}

\begin{abstract}
According to the waste-to-energy (WTE) valorization and circular economy principles, the use of waste oil and grease (WOG) for obtaining biofuels shows the tendency towards sustainability, makes the interest in green chemistry, and the development of environmentally friendly processes grow. Three different fatty wastes (from the fat trap of a sewage station, lard waste, and frying oil) were analyzed and this work showed they have no potentially toxic metals. The frying oil sample and residual lard waste showed a higher percentage of triacylglycerides resulting in higher biodiesel conversion. The samples showed physical and chemical properties (density, viscosity, and ash) within the limits established by current regulations. Bio-oil samples formed a mixture of carboxylic acids, with high acidity. However, the parameters that deviated from the maximum permitted by the standard could be adjusted blending with petroleum diesel, replacing partially the fossil energy carriers with biomass-derived energy carriers which could bring positive impacts from multiple perspectives, i.e., economic, environmental, and health.
\end{abstract}

Keywords: waste oils and grease, biofuels, biodiesel, bio-oil

\section{Introduction}

The production and employment of alternative fuels ${ }^{1-4}$ and the correct disposal of solid waste ${ }^{5,6}$ is a subject of discussion all over the world and also in Brazil, as a result of fossil fuel scarcity, global warming, climate change, and successive environmental tragedies, affecting populations and the ecosystem. In this framework, new solutions for waste disposal, ${ }^{7}$ renewable energy, and technological processes $^{8-14}$ are mandatory. In recent years, several laws have been created in Brazil for solid waste and biodiesel, ${ }^{15-17}$ and despite not being fully regulated, the mixture of liquid hydrocarbons produced during thermal pyrolysis of fatty materials also has properties very similar to petroleum diesel. ${ }^{18-20}$ The production of environmentally friendly biofuels applying residual fatty materials ${ }^{21,22}$ as feedstock is a groundbreaking way for waste management and production of energy and would also avoid soil and water pollution. ${ }^{23}$

Lamentably, landfills and sanitation systems are still the final destinations of large amounts of waste oils and grease (WOG), from commercial and domestic use, and

*e-mail: psuarez@unb.br; psuarez666@gmail.com;

ghesti.grace@gmail.com

Editor handled this article: Brenno A. D. Neto (Associate) the release to sewer reduces the diameter of pipes causing overflows and clogging ${ }^{24,25}$ and may also compromise the effluent treatment, mainly the biological process. ${ }^{26}$ In the UK, for example, primarily the annual sanitary overflows are caused exclusively by the clogging of greasy blocks, called "fatbergs". ${ }^{27}$ Free, emulsified, dispersed and solubilized forms of WOG are the main cause of pollution on wastewater, in a discrete and continuous way. ${ }^{28}$

He et al..$^{29}$ conducted a study of (fat, oil, and grease) FOG deposits formation mechanism from sewer lines in the United States. The samples had a high content of granulated particles, a sandy texture, and mostly contained up to $50 \%$ lipid content. These deposits are formed by carboxylates, products of the saponification reaction of fatty acids typically with alkaline and alkaline earth metals, such as magnesium, potassium, and calcium-this one as a result of the chemical and biochemical attack on concrete. The majority of fat chains had between 14-18 carbons (C14 and C18), preponderantly palmitic (C16) and oleic (C18:1) carboxylates.

FOG's proper management lacks enhancement, notably its correct final destination, and disposal of it with organic garbage on landfill is unreasonable and environmentally inappropriate. Seize the potential opportunity to generate income and produce bioenergy through transesterification 
and pyrolysis pathways play a key role in the circular economy once these waste-to-energy (WTE) processes produce biofuels analogous to fossil fuels.

Transesterification is a chemical reaction between a FOG and a monoalcohol, ${ }^{30}$ normally methanol, on three reversible semi-reactions: the conversion of triglycerides to diglycerides, then to monoglycerides until glycerol. In the end, three monoesters are produced from only one triacylglyceride. ${ }^{31}$ The use of methanol is preferable due to its low price and high reactivity. The reaction can also be catalyzed by both Lewis ${ }^{32-35}$ or Brönsted bases and acids, ${ }^{36-38}$ depending on FOG. Refined vegetable oils ${ }^{39}$ with low free fatty acid (FFA) content $(<0.5$ wt. $\%)$ are widely applied with alkaline catalysts and acid catalysts are employed with high FFA content (> 1.0 wt.\%), as WOG, to avoid soap formation. ${ }^{40,41}$

Pyrolysis of oils and fats consists of grease chains' cleavage, at high temperatures, with or without a catalyst. ${ }^{42,43}$ The primary products are a light gas fraction and a liquid enriched with hydrocarbons such as alkanes, alkenes, carboxylic acids, and aromatics, called bio-oil. The reaction mechanism is complex, but mainly is described to occur in two stages: $(i)$ first stage: primary cracking-triacyl glyceride decomposition: the disruption of $\mathrm{C}-\mathrm{O}$ bonds between the glyceride and the alkyl chain, leads to carboxylic acids, acrolein, and ketenes; (ii) second stage: secondary crackingthermal decarbonization or decarboxylation of fatty acid, forming alkanes, alkenes, and gases.

Parallel reactions may happen, such as cycling of long chains, dimerization of FFA, or formation of aromatics (from the dehydrogenation of cycloalkanes). The high temperature and the formation of gases is thermodynamically favorable. ${ }^{44,45}$ Nevertheless, the low selectivity leads to a combination of compounds. If the feedstock has a high content of FFA, such as WOG, the bio-oil tends to lower oxygenation. Bio-oils largely have similar physical and chemical characteristics to petroleumderived fuels that make them desirable to build a diversified and renewable energy matrix, such as the Brazilian one. Furthermore, the exploitation of this waste as feedstock, significantly impacts the cost reduction of the process, enhancing profitability. ${ }^{46-49}$

In this work, the three fatty wastes were converted into methyl esters and bio-oils through pyrolysis and their physical-chemical properties were evaluated.

\section{Experimental}

About $5 \mathrm{~kg}$ of three different fatty wastes samples were collected: ( $i$ ) a sample obtained from the fat trap of a local Wastewater Treatment Plant Station (CAESB's WWTP) in Brasília, Brazil; (ii) soybean oil subjected to a frying process in a restaurant; (iii) lard generated during baking lard. The samples were decanted and filtered to remove coarse materials and aqueous phases.

The biodiesel was made through esterification and transesterification. The esterification was carried out refluxing in a glassware $200 \mathrm{~g}$ of the fatty waste, $70 \mathrm{~mL}$ of methanol (Vetec, RJ, Brazil), and $2 \mathrm{~g}$ of sulfuric acid (Vetec, RJ, Brazil) (1\% weight/weight) for $2 \mathrm{~h}$ at $60{ }^{\circ} \mathrm{C}$ under continuous stirring, when the acid number was higher than $100 \mathrm{mg} \mathrm{KOH} \mathrm{g}^{-1}$ oil. For other samples, the transesterification was made by the addition of $\mathrm{KOH}$ (Vetec, RJ, Brazil) and methanol in the proportion of 1:40 (1 KOH and $40 \mathrm{wt} . \%$ methanol) and refluxing in glassware for $2 \mathrm{~h}$ at $60{ }^{\circ} \mathrm{C}$ under continuous magnetic stirring. Then, the product was purified, washed several times, solubilized in dichloromethane (Vetec, RJ, Brazil), kept standing over magnesium sulfate, filtered and the solvent was evaporated under a vacuum pump.

In the pyrolysis reaction, $200 \mathrm{~g}$ of the WOG samples were cracked using glassware in the temperature range between 350 and $400{ }^{\circ} \mathrm{C}$ and interrupted when $75 \%$ of the initial amount had been converted to the liquid. The vapors were condensed and collected in a pre-weighed flask.

The physical-chemical properties of the fatty materials and biofuels were analyzed according to the standards established by the Brazilian National Agency of Petroleum, Natural Gas and Biofuels (ANP) for biodiesel: ASTM D445, ${ }^{50}$ NBR 7148, ${ }^{51}$ ASTM D189, ${ }^{52}$ ASTM D874, ${ }^{53}$ EN $14111^{54}$ AOCS 3d-63. ${ }^{55}$

The conversion of FOG into FAME (fatty acid methyl esters) was measured employing high-performance liquid chromatography (HPLC) using a Shimadzu CTO-20A chromatograph (Tokyo, Japan), equipped with a UV-Vis detector (205 nm) and a Shim-pack VP-ODS column-C18, $250 \mathrm{~mm}, 4.6 \mathrm{~mm}$ of internal diameter. The bio-oil samples were analyzed by gas chromatography coupled with a mass spectrometer (GC-MS), using a Shimadzu model GC-MS-QP5050 (Tokyo, Japan) equipment with a capillary column of melted silicate CBPI PONA 50 m length, $0.15 \mu \mathrm{m}$ diameter, and $0.42 \mu \mathrm{m}$ thickness. Both chromatographic analyses were made accordingly to Carvalho et al. ${ }^{56}$ Fourier transform infrared (FTIR) spectra were carried out in a Shimadzu Prestige-21 (Tokyo, Japan) equipped with attenuated total reflectance (Pike Technologies, Fitchburg, Wisconsin, USA), between 600 and $4000 \mathrm{~cm}^{-1}$, with 32 interferograms. Inductively coupled plasma atomic emission spectrometry (ICP-OES) analyses were measured using an iCAP 6300 Duo ICP optical emission spectrometer (Thermo Fisher Scientific, Cambridge, England). 


\section{Results and Discussion}

The fat trap sample from the sewage station was solid, with a very strong smell and highly impurity content while the frying oil had no smell and no significant solid particles, and was liquid at room temperature. Lard waste was an intermediate: partially solid, no strong smell, but with some food scraps. The fat trap sample will be called by the acronym FTW, while the frying oil and lard waste will be called FO and LW, respectively. Initially, the three fatty residues were characterized, and physical-chemical parameters are listed in Table 1.

Table 1. Physical chemical properties of waste oil and grease-FTW (fat trap waste), LW (lard waste), FO (frying oil)

\begin{tabular}{|c|c|c|c|}
\hline Physical chemical property & FTW & LW & FO \\
\hline Iodine index / $\left(\mathrm{mg} \mathrm{I}_{2} \mathrm{~g}^{-1}\right)$ & 44.9 & 53.9 & 61.0 \\
\hline Density at $20^{\circ} \mathrm{C} /\left(\mathrm{g} \mathrm{m}^{-3}\right)$ & 892 & 926 & 918 \\
\hline Viscosity at $40{ }^{\circ} \mathrm{C} /\left(\mathrm{mm}^{2} \mathrm{~s}^{-1}\right)$ & 27.1 & 43.8 & 35.3 \\
\hline Acidity / (mg KOH g ${ }^{-1}$ oil) & 175.6 & 1.3 & 1.7 \\
\hline Fatty acid and monoglyceride / wt.\% & 90 & 9 & 4 \\
\hline Dyacilglyceride / wt.\% & 5 & 3 & 8 \\
\hline Triacylglyceride / wt.\% & 5 & 87 & 87 \\
\hline Methyl ester / wt.\% & 0 & 1 & 1 \\
\hline
\end{tabular}

FTW has almost ten times more acidity (175.6 $\mathrm{mg} \mathrm{KOH} \mathrm{g}^{-1}$ oil) compared to the LW and FO (1.3 and $1.7 \mathrm{mg} \mathrm{KOH} \mathrm{g}^{-1}$ oil) due to $90 \%$ content of free fatty acid and monoglyceride, related to a higher degree of hydrolyzation and hydrogenation of the $\pi$ bonds, also shown by the lower iodine index ( $\left.44.9 \mathrm{mg} \mathrm{I}_{2} \mathrm{~g}^{-1}\right)$, which is coherent to brown grease samples. ${ }^{57}$ The analysis of infrared spectroscopy, Figure 1, reveals a predominantly FFA (free fatty acid) profile in FTW: broadband between 3000 and $3500 \mathrm{~cm}^{-1}$ related to $\mathrm{O}-\mathrm{H}$ of acid groups. Intense $\mathrm{C}=\mathrm{O}$ bands $\left(1710 \mathrm{~cm}^{-1}\right)$, usually are observed when occurs free fatty acids dimerization by hydrogen bandings. It suggests the hydrolysis of FTW on sewage network. In FO and LW spectra, $\mathrm{C}=\mathrm{O}$ in $1770 \mathrm{~cm}^{-1}$ is associated with the displacement of carbonyl caused by the expressive amount of triacylglycerides (87\%) and low acidity $\left(<2.0 \mathrm{mg} \mathrm{KOH} \mathrm{g}^{-1}\right.$ oil), higher viscosity and density. The bands between 2800 and $2960 \mathrm{~cm}^{-1}$ in all samples are due to $\mathrm{sp}^{3}$ carbon in an alkyl chain.

ICP-OES analysis (Figure 2) makes a broad analysis of the chemical elements and emphasizes the absence of potentially toxic metals such as $\mathrm{Pb}, \mathrm{Cd}, \mathrm{Cr}$, what is suitable for green biofuels production and even the sulfur content of FTW (1.5 ppm) is ten times lower than maximum standards, $15 \mathrm{ppm}$. The phosphorus content on LW and FTW is related

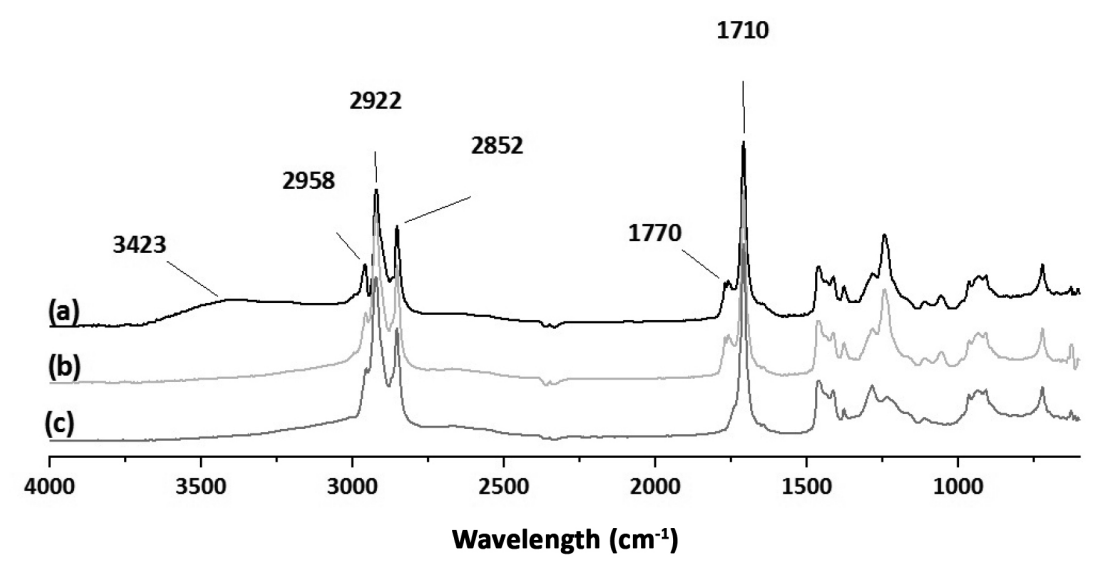

Figure 1. FTIR (ATR) spectra of (a) FTW (fat trap waste), (b) LW (lard waste), and (c) FO (frying oil).

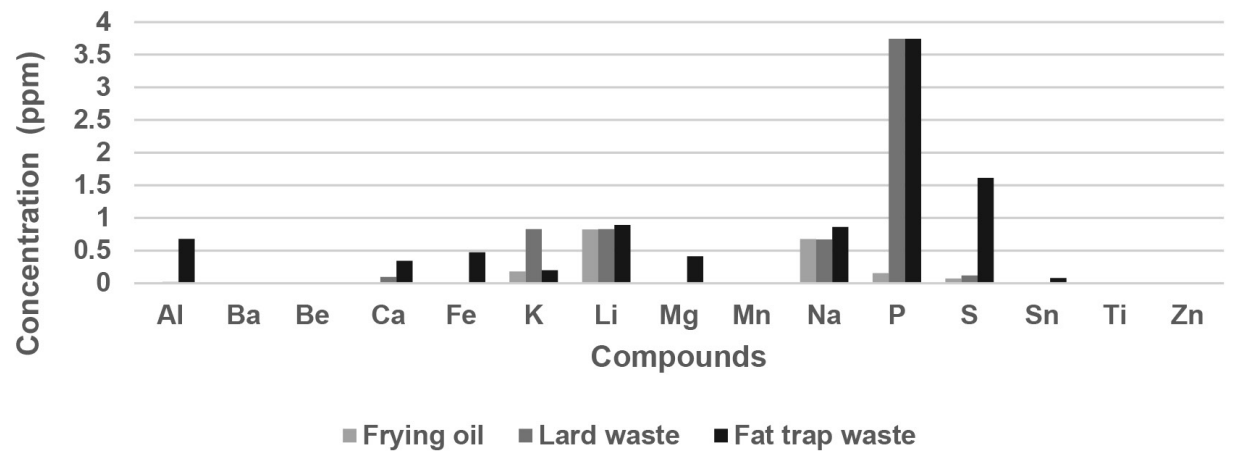

Figure 2. ICP-OES of frying oil, lard waste, and fat trap waste. 
Table 2. Physical-chemical properties of fat trap biodiesel (FTWBD), lard waste biodiesel (LWBD), frying oil biodiesel (FOBD), fat trap bio-oil (FTWBO), lard waste bio-oil (LWBO), frying oil bio-oil (FOBO)

\begin{tabular}{|c|c|c|c|c|c|c|c|}
\hline Test & FTWBD & LWBD & FOBD & FTWBO & LWBO & FOBO & Limits \\
\hline Density at $20^{\circ} \mathrm{C} /\left(\mathrm{g} \mathrm{m}^{-3}\right)$ & 876 & 874 & 884 & 880 & 860 & 874 & 865 \\
\hline Viscosity at $40{ }^{\circ} \mathrm{C} /\left(\mathrm{mm}^{2} \mathrm{~s}^{-1}\right)$ & 6.14 & 4.54 & 4.34 & 8.47 & 7.29 & 7.03 & $1.9-6.0$ \\
\hline Acidity / (mg KOH g-1 oil) & 0.2 & 0.2 & 0.2 & 127.9 & 123.2 & 116.9 & 0.50 \\
\hline Carbon residue / wt. $\%$ & 0.01 & 0.01 & 0.01 & 1.2 & 1.8 & 1.5 & 0.050 \\
\hline Sulfated ash / wt. $\%$ & 0.01 & 0.01 & 0.01 & 0.01 & 0.01 & 0.01 & 0.020 \\
\hline
\end{tabular}

to phospholipids, absent in vegetal samples. The content of $\mathrm{Ca}, \mathrm{Mg}, \mathrm{Na}$, and $\mathrm{K}$ are far from the maximum limit standards, $5.0 \mathrm{ppm}$.

The physical-chemical parameters of the biofuels (biodiesel and bio-oils) are presented in Table 2. The density and viscosity of all products are lower than raw materials and the acidity and carbon residue of formed biodiesel are smaller than bio-oil. Only sulfated ash is within limit standards. However, the blend of different content of biofuels into petrodiesel could correct such distortions since the current proposal is the gradual diversification of the energy matrix.

The bio-oils required an additional analysis due to the great mixture of chemical components and GC-MS analysis was performed. The most concentrated ones are shown in Figures 3, 4, 5. As can be depicted, the fat trap bio-oil (FTWBO), Figure 3, derived bio-oil formed saturated fatty acid, mainly $\mathrm{C} 18$ (stearic and oleic) and C16 (palmitic) also seen in the LWBO, Figure 4, while FOBO, Figure 5, is composed by oleic acid, although an aldehyde (decenal) was described. No aromatic compounds were detected. As can be observed, the three bio-oils have a high acidity index, which was expected because of the carboxylic acids identified by GC-MS.

\section{FTWBO}

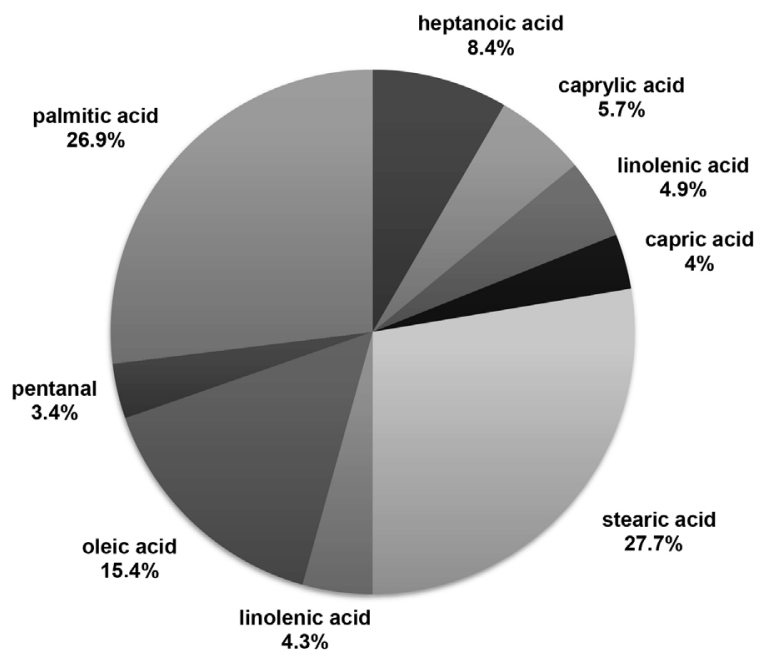

Figure 3. Composition of fat trap bio-oil (FTWBO).

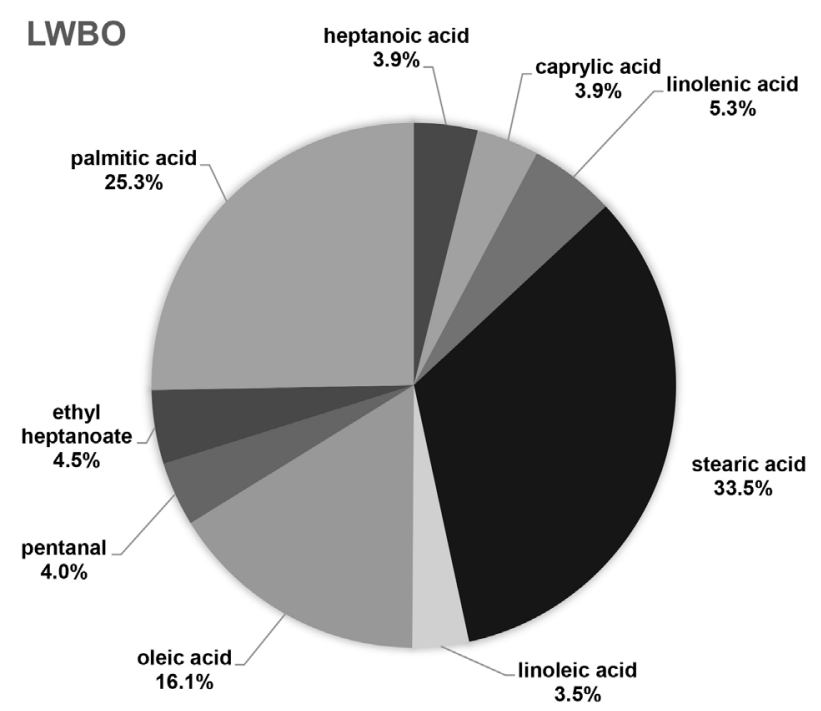

Figure 4. Composition of lard waste bio-oil (LWBO).

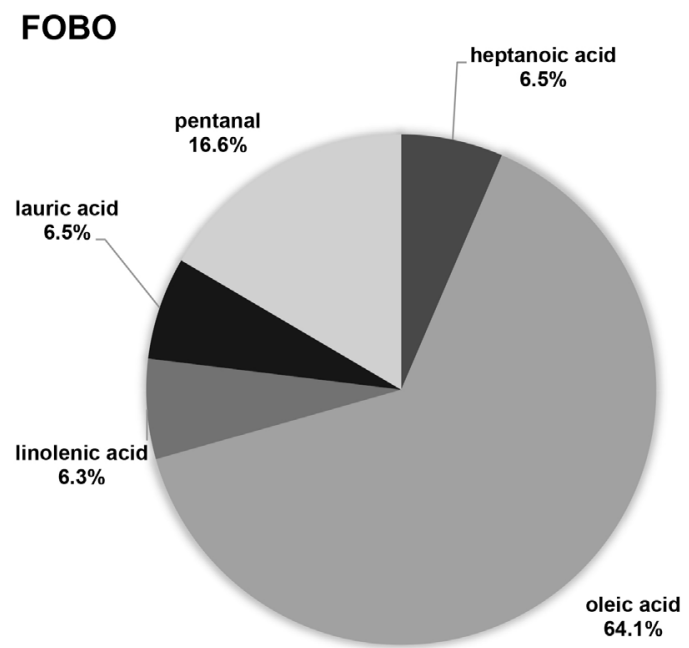

Figure 5. Composition of frying oil bio-oil (FOBO).

\section{Conclusions}

This work demonstrated that WOG from sewage networks or other residual sources can be used to produce biodiesel that matches the Brazilian and international specifications. In addition to reducing the cost of production, by using low-cost feedstocks, employing circular economy principles also provide an alternative for recycling this 
waste and avoiding water contamination. It was also possible to produce bio-oils enriched with carboxylic acids from the pyrolysis of the three different WOGs. Despite the high acidity index, the bio-oils presented relevant physical-chemical parameters, demonstrating the potential to be used as an alternative energy source. Furthermore, upgrading bio-oil production through decarboxylation or hydrodeoxygenation could correct some properties and parameters, promoting the development of waste-to-energy processes.

\section{Acknowledgments}

The authors would also like to thank the support of the National Council for Scientific and Technological Development (CNPq), Federal District Research Support Foundation (FAPDF), and the Institute of Chemistry of the University of Brasília (IQ/UnB).

\section{Author Contributions}

Lyvia N. B. Menezes was responsible for formal analysis, investigation, methodology, writing an original draft, writing review and editing; Paulo A. Z. Suarez for conceptualization, funding acquisition, investigation, project administration, writing review and editing; Grace F. Ghesti for conceptualization, funding acquisition, investigation, writing review and editing.

\section{References}

1. Rodrigues, J. P.; Suarez, P. A. Z.; Ghesti, G. F.; Iha, O. K.; Reis, I. B.; Lavich, R. R.; Int. J. Sustainable Eng. 2021, 14, 1800.

2. Tan, H.; Li, J.; He, M.; Li, J.; Zhi, D.; Qin, F.; Zhang, C.; J. Environ. Manage. 2021, 297, 113382.

3. Srivastava, R. K.; Shetti, N. P.; Reddy, K. R.; Aminabhavi, T. M.; Environ. Chem. Lett. 2020, 18, 1049.

4. Kaniapan, S.; Hassan, S.; Ya, H.; Nesan, K. P.; Azeem, M.; Sustainability 2021, 13, 3110.

5. Mills, N.; Pearce, P.; Farrow, J.; Thorpe, R. B.; Kirkby, N. F.; Waste Manage. 2014, 34, 185.

6. Sivalingam, S.; Sen, S.; Environ. Sci. Pollut. Res. 2019, 26, 34693.

7. Barampouti, E. M.; Mai, S.; Malamis, D.; Moustakas, K.; Loizidou, M.; Renewable Sustainable Energy Rev. 2019, 110, 298.

8. Aghbashlo, M.; Tabatabaei, S.; Soltanian, H.; Ghanavati, H.; Renewable Energy 2019, 143, 64.

9. Krounbi, L.; Enders, A.; van Es, H.; Woolf, D.; van Herzen, B.; Lehmann, J.; Waste Manage. 2019, 89, 366.

10. Astrup, T. F.; Tonini, D.; Turconi, R.; Boldrin, A.; Waste Manage. 2015, 37, 104.
11. Guimarães, M. G.; Evaristo, R. B. W.; de Mendonça Brasil, A. C.; Ghesti, G. F.; SN Appl. Sci. 2021, 3, 283.

12. Guimarães, M. G.; Evaristo, R. B. W.; de Macedo, J. L.; Ghesti, G. F.; J. Braz. Chem. Soc. 2022, 33, 327.

13. Miranda, M. R. S.; Veras, C. A. G.; Ghesti, G. F.; Waste Manage. 2020, 103, 177.

14. Evaristo, R. B. W.; Viana, N. A.; Guimarães, M. G.; do Vale, A. T.; de Macedo, J. L.; Ghesti, G. F.; Biomass Convers. Biorefin. 2020, DOI: 10.1007/s13399-020-00821-y.

15. Presidência da República Casa Civil; Lei No. 12.305, de 02 de agosto de 2010, Institui a Política Nacional de Resíduos Sólidos; Diário Oficial da União (DOU), Brasília, Brazil, 2010, available at http://www.planalto.gov.br/ccivil_03/_ato2007-2010/2010/ lei/112305.htm, accessed in January 2022.

16. Presidência da República Casa Civil; Lei No. 11.097, de 13 de janeiro de 2005, Dispõe sobre a Introdução do Biodiesel na Matriz Energética Brasileira; Diário Oficial da União (DOU), Brasília, Brazil, 2005, available at http://www.planalto.gov. br/ccivil_03/_ato2004-2006/2005/lei/111097.htm, accessed in January 2022.

17. Presidência da República Casa Civil; Lei No. 13.576, de 26 de dezembro de 2017, Dispõe sobre a Política Nacional de Biocombustíveis (RenovaBio); Diário Oficial da União (DOU), Brasília, Brazil, 2017 , available at http://www.planalto.gov. br/ccivil_03/_ato2015-2018/2017/lei/113576.htm, accessed in January 2022.

18. Chen, X.; Zhang, Y.; Xu, B.; Li, Y.; Energy 2022, 239, 121921.

19. Wisniewski Jr., A.; Wosniak, L.; Scharf, D. R.; Wiggers, V. R.; Meier, H. F.; Simionatto, E. L.; J. Braz. Chem. Soc. 2015, 26, 224.

20. Ali, L.; Baloch, K. A.; Palamanit, A.; Raza, S.A.; Laohaprapanon, S.; Techato, K.; Sustainability 2021, 13, 5942.

21. Abomohra, A. E.; Elsayed, M.; Esakkimuthu, S.; Prog. Energy Combust. Sci. 2020, 81, 100868 .

22. Sander, A.; Košcak, M. A.; Kosir, D.; Milosavljević, N.; Vuković, P.; Magić, L.; Renewable Energy 2018, 118, 752.

23. Wallace, T.; Gibbons, D.; O’dwyer, M.; Curran, T. P.; J. Environ. Manage. 2017, 187, 424.

24. Kusum, S. A.; Pour-Ghaz, M.; Ducoste, J. J.; Water Res. 2020 , 186, 116304.

25. Roychand, R.; Li, J.; de Silva, S.; Saberian, M.; Law, D.; Pramanik, B. K.; Resour., Conserv. Recycl. 2021, 164, 105166.

26. Rodríguez, J. P.; McIntyre, N.; Díaz-Granados, M.; Maksimović, C.; Water Res. 2012, 46, 4571.

27. Michael, M.; Soc. Stud. Sci. 2020, 50, 377.

28. Williams, J. B.; Clarkson, C.; Mant, C.; Drinkwater, A.; May, E.; Water Res. 2012, 46, 6319.

29. He, X.; Iasmin, M.; Dean, L. O.; Lappi, S. E.; Ducoste, J. J.; de los Reyes, F. L.; Environ. Sci. Technol. 2011, 45, 4385.

30. Brandão, R. F.; Quirino, R. L.; Mello, V. M.; Tavares, A. P.; Peres, A. C.; Guinhos, F.; Rubim, J. C.; Suarez, P. A. Z.; J. Braz. Chem. Soc. 2009, $20,954$. 
31. Doll, K. M.; Sharma, B. K.; Suarez, P. A. Z.; Erhan, S. Z.; Energy Fuels 2008, 22, 2061.

32. Mello, V. M.; Pousa, G. P. A. G.; Pereira, M. S. C.; Dias, I. M.; Suarez, P. A. Z.; Fuel Process. Technol. 2011, 92, 53.

33. da Silva, F. M.; Pinho, D. M. M.; Houg, G. P.; Reis, I. B. A.; Kawamura, M.; Quemel, M. S. R.; Montes, P. R.; Suarez, P. A. Z.; Chem. Eng. Res. Des. 2014, 92, 1463.

34. Alves, M. B.; Medeiros, F. C. M.; Suarez, P. A. Z.; Ind. Eng. Chem. Res. 2010, 49, 7176.

35. Suarez, P. A. Z.; da Silva, F. M.; J. Braz. Chem. Soc. 2012, 23, 1201.

36. Ramalho, H. F.; di Ferreira, K. M. C.; Machado, P. M. A.; Oliveira, R. S.; Silva, L. P.; Prauchner, M. J.; Suarez, P. A. Z.; Ind. Crops Prod. 2014, 52, 211.

37. Abreu, F. R.; Lima, D. G.; Hamú, E. H.; Einloft, S.; Rubim, J. C.; Suarez, P. A. Z.; J. Am. Oil Chem. Soc. 2003, 80, 601.

38. Olkiewicz, M.; Plechkova, N. V.; Earle, M. J.; Fabregat, A.; Stüber, F.; Fortuny, A.; Font, J.; Bengoa, C.; Appl. Catal., B 2016, 181, 738.

39. Pinto, A. C.; Guarieiro, L. L. N.; Rezende, M. J. C.; Ribeiro, N. M.; Torres, E. A.; Lopes, W. A.; Pereira, P. A. P.; de Andrade, J. B.; J. Braz. Chem. Soc. 2005, 16, 1313.

40. Rezende, M. J. C.; de Lima, A. L.; Silva, B. V.; Mota, C. J. A.; Torres, E. A.; da Rocha, G. O.; Cardozo, I. M. M.; Costa, K. P.; Guarieiro, L. L. N.; Pereira, P. A. P.; Martinez, S.; de Andrade, J. B.; J. Braz. Chem. Soc. 2021, 32, 1301.

41. Bi, C.-H.; Min, M.; Nie, Y.; Xie, Q.-L.; Lu, Q.; Deng, X.-Y.; Anderson, E.; Li, D.; Chen, P.; Ruan, R.; Bioresour. Technol. 2015, 185, 185.

42. Mello, V. M.; Martins, G. B. C.; Montenegro, M. A.; Suarez, P. A. Z.; Ind. Crops Prod. 2015, 66, 255.

43. Santos, A. L. F.; Martins, D. U.; Iha, O. K.; Ribeiro, R. A. M.; Quirino, R. L.; Suarez, P. A. Z.; Bioresour. Technol. 2010, 101, 6157.
44. Andrade, R. D. A.; Pozzebom, E.; Faria, E. A.; Dantas Filho, F.; Suarez, P. A. Z.; do Prado, A. G. S.; Acta Sci. 2011, 34, 243.

45. Ranzi, E.; Debiagi, P. E. A.; Frassoldati, A.; ACS Sustainable Chem. Eng. 2017, 5, 2867.

46. Liobikienè, G.; Dagiliūtè, R.; Energy 2021, 231, 120817.

47. Geng, J. B.; Liu, C.; Ji, Q.; Zhang, D.; Renewable Sustainable Energy Rev. 2021, 150, 111429.

48. Liao, C.; Erbaugh, J. T.; Kelly, A. C.; Agrawal, A.; Renewable Sustainable Energy Rev. 2021, 145, 111063.

49. Kuang, W.; J. Cleaner Prod. 2021, 302, 127006.

50. ASTM D445: Standard Test Method for Kinematic Viscosity of Transparent and Opaque Liquids (and Calculation of Dynamic Viscosity), West Conshohocken, PA, 2011.

51. ABNT NBR 7148: Petróleo e Derivados de Petróleo Determinação da Massa Específica, Densidade Relativa e 'API - Método do Densímetro, Rio de Janeiro, 2013.

52. ASTM D189: Standard Test Method for Conradson Carbon Residue of Petroleum Products, West Conshohocken, PA, 2010.

53. ASTM D874-07: Standard Test Method for Sulfated Ash from Lubricating Oils and Additives, West Conshohocken, PA, 2007.

54. EN 14111: Fat and Oil Derivatives-Fatty Acid Methyl Esters (FAME) Determination of Iodine Value, Brussels, 2003.

55. American Oil Chemists' Society (AOCS); AOCS Official Method Cd 3d-63: Acid Value of Fats and Oils, Champaign, 2017.

56. Carvalho, M. S.; Mendonça, M. A.; Pinho, D. M. M.; Resck, I. S.; Suarez, P. A. Z.; J. Braz. Chem. Soc. 2012, 23, 763.

57. Bashir, M. J. K.; Wong, L. P.; St. Hilaire, D.; Kim, J.; Salako, O.; Jean, M. J.; Adeyemi, R.; James, S.; Foster, T.; Pratt, L. M.; J. Environ. Chem. Eng. 2020, 8, 103848.

Submitted: October 8, 2021 Published online: January 11, 2022 